\title{
Discussion on the Construction of the Management Accounting System in the Administrative Institutions
}

\author{
Hui Wen \\ Department of Financing and Auditing \\ Military Academy of Service and Command \\ Wuhan City, PRC., 430035 \\ 375081403@163.com
}

\author{
Herong Mao* \\ School of Foreign Languages \\ Hubei University of Chinese Medicine \\ Wuhan City, PRC., 430065 \\ 314505324@qq.com
}

\begin{abstract}
As the reform on the administrative institutions in China deepens, it's quite necessary to carry out a discussion on how to construct the management accounting system in the administrative institutions so as to improve their efficiency and integrity. This article starts with the importance of constructing the management accounting system in the administrative institutions from three perspectives, then points out the problems faced with in the process of construction, and finally offers the countermeasures that may be applied in practice. It can be seen that the construction of the management accounting system in the administrative institutions is a complicated and relatively long process, which will reduce the administrative cost and improve the administrative efficiency.
\end{abstract}

Keywords-the management accounting system; the administrative institutions; problems; countermeasures

\section{INTRODUCTION}

With the continuous deepening of the socialist reforms, the importance and urgency of the system reform of China's administrative institutions has been further highlighted. The administrative institutions, as the state organs, provide services for the supervision of law enforcement and social management in the country. With the sound, rapid and standardized development of the socialist market economy, it is particularly important to introduce the management accounting system to effectively supervise and regulate the economic and business transactions within the administrative institutions. On the other hand, with the deepening and improvement of China's fiscal and tax reforms, the establishment of a modern financial system, the promotion of budget performance management of the administrative institutions and building of the governance structure of the administrative institutions as a legal person have become the inevitable appeal of related institutions in carrying out the management accounting work. In this context, under the guidance of the Accounting Law of the People's Republic of China, the Budget Law of the People's Republic of China and other relevant laws, regulations and provisions, the Ministry of Finance and other relevant departments have issued a series of related policies and regulations, which have made detailed provisions and explanations on the behaviors of the management accounting in the administrative institutions. The successive introduction and improvement of relevant norms have laid a solid institutional foundation for the construction of the management accounting and guided a further development of the management accounting in the administrative institutions.

\section{THE IMPORTANCE OF CONSTRUCTION OF THE MANAGEMENT SySTEM IN THE CHINESE ADMINISTRATIVE INSTITUTIONS}

As the saying goes, management creates benefits. The management accounting is an all-round management activity concerning the enterprise planning, decision-making, control and evaluation from the perspective of economy. As the reform and opening up deepen, especially as the reform of the Chinese government departments deepens, the management accounting of the public departments is playing a more and more important role in improving the work efficiency and service level of relevant departments, the management transparency of the administrative institutions as well as the scientific management of the administrative institutions.

\section{A. Removing the Public Accountability of the Administrative Institutions to Improve the Management Transparency}

With the establishment of the democratic social system, the administrative institutions have been endowed with the responsibility of public trust. However, due to the long chain of principal-agent and the untimely communication, it easily leads to the information asymmetry between the two parties on the one hand. On the other, due to the uneven distribution of rights among various departments and interests in all aspects, it is easy to bring about various contradictions or disputes. For the absence of owners and the lack of effective incentive mechanism, the key to solving these problems lies in the establishment of a supervision mechanism. It's firmly believed that the effective supervision must be based on the reliability, relevance and integrity of information. With the rise of the public management movement, the administrative institutions provide comprehensive and relevant information and accept the internal and external accounting information user evaluation, which is the key to removing the public fiduciary responsibility. As we know, the administrative management accounting helps the public fully understand the diversified behaviors of the government and the entrusted performance, 
which makes up for the unpredictability of government behaviors [1]. Therefore, the construction of a sound management accounting system for the administrative institutions, providing more comprehensive and relevant information as well as improving the management transparency relieve the government of the public fiduciary responsibility.

\section{B. Strengthening the Internal Control of the Administrative Institutions to Improve the Scientific Management}

The construction of the management accounting system of the administrative institutions can provide relevant information needed for decision-making, control, evaluation and communication. Among them, the internal control, risk assessment, risk management and internal supervision can help the government departments to evaluate the internal and external risks so as to strengthen the internal control and improve the comprehensive level of the administrative management in the relevant institutions. However, unable to provide a good environment for the construction of the management accounting, there are still imperfections faced with the internal control system of the current Chinese administrative institutions. The main problems are as follows:

Firstly, the responsibility and division of labor are still unclear, so quite a few professionals occupy a few positions, the principle that incompatible positions held by different people is not followed, and the development of the internal check system still needs to be improved, all these are not good for the effective supervision and conduct of the management accounting work. Secondly, the management accounting business process is not standardized. What's more, the budget management is still unscientific. Last but not the least, the supervision mechanism and risk assessment system are not sound either. In view of the current situation, establishment of a sound management accounting system for the administrative institutions will help improve the construction of the internal control system for the administrative institutions and improve the service level and scientific management of the administrative institutions with the relevant accounting information.

\section{Reducing the Administrative Operation Cost to Improve the Efficiency of Administrative Service}

China's reform and opening up in the past years inevitably brings forth the establishment of socialist market economic system. In order to adapt to the needs of economic and social development, the Chinese government has been committed to reforming the government management institutions and systems. The Third Plenary Session of the 19th Central Committee of the communist party of China (CPC) had pointed out that it is an important task to deepen the reform of the party and state institutions, to transform and optimize the government functions, which requires the administrative institutions to reform the existing organizational structure and give full play to their existing functions. Meanwhile, the evaluation standard of relevant information and the way of performance incentive should also be changed correspondingly due to the change of the organizational structure. However, because of the long-term lack of effective management accounting information system, it's a widespread phenomenon that the decision-making and service efficiency of the Chinese administrative institutions has remained comparatively low. Therefore, the decision-making and management methods in the management accounting should be used to provide more valuable and abundant information for the managers of the administrative institutions so as to improve their decision-making efficiency [2]. In other words, the administrative institutions need to build a sound management accounting system to reduce the administrative costs and accelerate their reform process.

\section{The Problems FACED With CONSTRUCtion OF THE MANAGEMENT SYSTEM IN THE CHINESE ADMINISTRATIVE INSTITUTIONS}

\section{A. The Unclear Disciplinary Orientation and the Undefined Disciplinary Connotation}

Juxtaposed with financial accounting, the management accounting is separated from the traditional accounting system. Initially, the management accounting is a branch of enterprise accounting, which focuses on making optimal decisions for enterprises, promoting business operation and management and improving the economic benefits. In China, the past two decades has witnessed the application of the management accounting into the administrative institutions. However, with multiple themes, backgrounds and theories, the management accounting, especially the management accounting in the administrative institutions, is a highly complicated and interdisciplinary discipline. There are still many problems faced with the disciplinary orientation and connotation of the management accounting in the administrative institutions. Due to the fact that the financial accounting personnel of the administrative institutions don't graduate from financial accounting and other related majors, there are quite a number of financial staffs who are unfamiliar with the different functions of the management accounting and financial accounting, some of them even simply hold that the financial accounting and the management accounting are the same thing. So, it is no wonder that they mix the content of the management accounting with the function of the financial and accounting management. When it comes to the function setting, many employees mistakenly believe that the management accounting is not indispensable, some even try to assign the function of the management accounting to each department. Therefore, the management accounting find it difficult in practice to really play a role of management and it's unfavorable for the management accounting to give full play to the overall efficiency of the administrative institutions [3].

\section{B. The Hysteretic Theoretical Layout Restricting the Effective Practice}

In 2014, the Ministry of Finance put forward Guidance on Comprehensively Promoting the Construction of the Management Accounting System, which had clearly pointed out the importance of strengthening the theoretical construction of the management accounting. Due to the relatively short history and lack of sufficient experience in the 
application of the management accounting, the theoretical development of the management accounting in the administrative institutions still far lags behind [4], which are demonstrated in the following aspects:

To begin with, the administrative institutions still apply the past traditional accounting model, which hasn't fully changed the concept of accounting and the accounting methods haven't been updated so far. Secondly, the theoretical construction of the management accounting hasn't kept pace with the times. With the advent of big data and rapid changes in the market, it is particularly urgent to establish a corresponding theoretical system of the management accounting. Thirdly, many administrative institutions in China haven't considered the actual situation of their own development and then put into use rationally. They have just copied some developed countries or the advanced theory of enterprise management accounting. All these have seriously restricted the conduct of effective practical activities in reality.

\section{The Out-dated Informatization Proficiency Hindering the Integration of Business and Finance}

With the advent of new technologies like the big data and cloud computing, fundamental changes are taking place in the production, processing and transmission of information. In order to keep up with the times, the administrative institutions should make great efforts to construct their information system. The cooperation and communication between departments and the superior and subordinate organizations do not only need accounting statements but also information related to the management accounting data for analysis and decision-making. Thus, the financial information and nonfinancial information should be used to predict or evaluate the past, present and future business activities. However, from the current situation of the information construction in the administrative institutions, the information work is mainly based on accounting, and the use and analysis of the financial data at early stage is far from adequate. So it is difficult to put into use the data in an effective way. At the same time, the asset management, financial management, information management and other systems are isolated from each other, and the degree of information resources sharing is low, which results in the difficulty in the effective integration of industry and finance [5]. Moreover, the financial soft-wares are deficient in the application of the financial management module in most of the administrative institutions, that's why the security and universality are poor too.

\section{The Shortage of Professional Talents and Professional Standards of the Management Accounting}

In the era of the knowledge economy, the key to innovation lies in talents. It is very important to give full play to the role of talents in the construction of the management accounting. Under the traditional accounting model, the main work of accounting is tally, keeping accounts and reimbursement, mainly reflected by the post-event business. With the development of economy and the advent of the information age, it is urgent for the administrative institutions to introduce management accounting talents with broad vision and profound professional knowledge. Seen from the current situation, the shortage of management talents in China's administrative institutions is becoming increasingly prominent. In fact, the management accounting has posed higher requirements for the accounting talents, not only in terms of professional quality, but also in terms of professional ethics. Lacking systematic understanding of the theoretical knowledge of the management accounting, most of the present accounting talents are directly engaged in the management accounting work in the traditional accounting model. On the other hand, in terms of professional ethics, irregular operation, accounting fraud and other problems are faced with some accounting personnel in the management accounting work, which results in the distortion of accounting information, and this in turn hinders the due role of the management accounting in the administrative institutions.

\section{ThE COUNTERMEASURES OF CONSTRUCTION OF THE MANAGEMENT System IN THE CHINESE AdMINISTRATIVE INSTITUTIONS}

\section{A. Strengthening Training and Further Education of the Management Accounting Professionals}

From our standpoint, exploration should be made in the mode of cooperative training between the public institutions and universities. The administrative institutions should take into consideration cooperating with colleges and universities to train the management accounting talents. Also, the investment should be increased in the personnel training costs. Through training, the professionals will have a systematic understanding and grasp of the current theory of the management accounting. They should not only learn the theoretical knowledge but also receive the professional ethics education. In addition, students in colleges and universities should also take part in the practical work of the management accounting to improve their practical ability to prepare for their future occupations. Through practice, the excellent college graduates should be introduced to work organizations, thus improving the overall proficiency of the management accounting talents.

On the other hand, due attention should be paid to the further education of the management accounting talents. With the rapid changes in the economy and society, the theory and practice of the management accounting are also in constant development. Therefore, the management accounting talents should keep pace with the times and constantly update their own knowledge reserves.

\section{B. Cultivating the Management Culture and Creating a Strong Professional Atmosphere for the Management Accounting Practitioners}

The people-oriented management culture is an extremely important organizational culture of the administrative institutions. As is well-known, the organizational culture is the core value of the administrative institution. Once the organizational culture is forged, it will be constantly exerted in practice, forming into the group values and becoming the driving force to motivate employees to keep fighting ahead. The people-oriented management culture aims to give employees the space for self-development and stimulate the 
spirit of ownership of workers. Each institute ought to improve the quality of workers ceaselessly, energetically training and remolding the workers' cultural value, concept of market economy, aesthetic view and mode of thinking. The management method should not only have the rigidity but also flexibility, which organically integrates the eastern and western cultures and build it into an inexhaustible source of power for the development and progress of the organization.

\section{Promoting the Establishment and Development of China Association of Management Accountants}

Generally, the western developed countries have the association of management accountants as a professional organization of the management accountants. The establishment of these professional organizations does not only promote the application and development of the management accounting in enterprises, but also strengthens the social status of the management accountants. In western developed countries, the accountants are considered to have extensive theoretical knowledge and rich practical experience once they hold a certificate of the chartered management accountant, which is extremely important for big companies in recruiting employees. It is necessary for China to learn from the advanced experience of the west, that is, to set up an association of management accountants with Chinese characteristics, set a qualification examination for the management accountants, and establish a series of related journals for the management accountants, which will not only contribute to the development of management accounting, but also promote the use and development of management accounting.

\section{CONCLUSION}

With the continuous development of the new normal and the rise of economic activities, the government should perform the fiduciary responsibility, their financial and economic behaviors should be more strictly supervised by the public, and more emphasis should be put on the early warning and risk prevention. It's necessary to push forward the development of the management accounting in the administrative institutions.

The management accounting in the Chinese administrative institutions started relatively late and developed relatively slowly in China. Under the guidance of the Basic Principles of the Government Accounting Standards etc., the management accounting of the administrative institutions in China has made some new progress in the recent years. Still, there are quite a few problems. The most important problem lies in the superficiality and repeatability of academic research. When looking to the future, the management accounting in the Chinese administrative institutions have to pay attention to the following aspects in order to achieve healthy development [6]. Firstly, we should learn from the developed countries based on the current situation. In the theoretical research, construction of standards, practical application etc., Chinese management accounting of the administrative institution should constantly strengthen to learn from the advanced theory and classical practice, make great efforts to construct the management accounting theory and methodological system that are endowed with Chinese characteristics and adapt to the Chinese national conditions, comprehensively promote construction of the management accounting and achieve the reform goals of accounting as scheduled. Secondly, we should innovate the mechanism and achieve coordinated development. The management accounting of the administrative institution is a complex overall project, so we need to cooperate with many parties to innovate the mechanism. In today's world, different kinds of media are highly developed simultaneously. Therefore, we can widely publicize the management accounting concepts, tools and practical methods to create a good atmosphere for the development of the management accounting. Thirdly, we should promote construction of the management accounting guidance system. To this end, what we have to do in the future include, organizing and formulating the management accounting guidance system to promote its effective application, establishing the expert consultation mechanism of the management accounting to provide consultation for the construction and application of the management accounting guidance system and encouraging the administrative institutions to timely summarize and sort out the practical experience of the management accounting through cooperation with scientific research institutions, and so on.

\section{ACKNOWLEDGMENTS}

This paper is financially supported by the Provincial Accounting Association Program of Hubei (HBKJ 201609). In the writing of this paper, professor Zeng and some other colleagues have offered constructive suggestions in collecting and analyzing the materials. Thanks also go to the lovely students. Without the interaction with them and inspiration from them in the practical teaching, the completion of the paper is impossible.

\section{REFERENCES}

[1] Tang Xiaoyu, Research on the Internal Control System of China's Administrative Institutions. Institute of Fiscal Science of the Ministry of Finance, pp.2-4, 2013. (In Chinese)

[2] Pan Xiaoling, An Applied Study on the Management Accounting in the Administrative Institutions. Contemporary Accounting, 11, pp.39-40, 2018. (In Chinese)

[3] Ji Ping, A Study on Strengthening of the Management Accounting in the Administrative Institutions. Accounting Learning, 14, p.122, 2017. (In Chinese)

[4] Wang Rui, Research on Strengthening of the Management Accounting in the Administrative Institutions. Accounting Learning, 19, p.97, 2018. (In Chinese)

[5] Wang Jia, Thoughts on the Integration of Business and Finance in the Administrative Institutions. Tax Paying, 34, p.35, 2018. (In Chinese)

[6] Zhao Xiaomeng, The Past, Present and Future of the Chinese Management Accounting. Northern Economy and Trade, 11,pp.78-79, 2018. (In Chinese) 